\title{
Teori Feminisme: Sejarah, Perkembangan dan Relevansinya dengan Kajian Keislaman Kontemporer
}

\author{
Nuril Hidayati \\ Sekolah Tinggi Agama Islam Negeri Kediri, Indonesia \\ E-mail: enhayil@gmail.com
}

\begin{abstract}
Feminism as a system of ideas is a broad-based framework and study of social life and human experience that evolves from a women-centered perspective. It's long history is a mirror of the batle on how to bring about justice for humanity to be real. Feminism ignites the Muslim consciousness of the reality of gender inequality. This awareness leads to the understanding that the estrangement of gender imbalances begins with the disparity of the meaning of religious texts with the reality of the historicity. The fusion between feminist theory as part of modern theory and islamic studies (contemporary interpretation of religious law) offers the solution of humanitarian problems through a balanced of judgment in women and men. Finding relevant Islamic values in gender mainstreaming has a positive impact on social justice. Developing Islamic studies as how to find the esoteric value that underlies life within the framework of religious social transformation. Affirming that Islam does not merely address the classical and theological issues of Figh, but also inspires human beings to judge and treat their fellow human beings as God's creatures with dignity and prestige so it is natural to be respected and treated fairly.
\end{abstract}

Keywords: feminism; fiqh woman critiq; contemporary islamic studies; gender justice

Abstrak. Feminisme sebagai sistem gagasan sebagai kerangka kerja dan studi kehidupan sosial dan pengalaman manusia yang berevolusi dari perspektif yang berpusat pada perempuan. Ini sejarah panjang sebagai cerminan dari tanggung jawab tentang bagaimana mewujudkan keadilan bagi umat manusia menjadi nyata. Feminisme menyulut kesadaran Muslim tentang realitas ketidaksetaraan gender. Kesadaran ini mengarah pada pemahaman bahwa pengasingan ketidakseimbangan gender dimulai dengan perbedaan makna teks-teks agama dengan realitas historisitas. Perpaduan antara teori feminis sebagai bagian dari teori modern dan studi Islam (interpretasi kontemporer hukum agama) menawarkan solusi masalah kemanusiaan melalui keseimbangan penilaian pada wanita dan pria. Menemukan nilai-nilai Islam yang relevan dalam pengarusutamaan gender memiliki dampak positif pada keadilan sosial. Mengembangkan studi Islam sebagai cara menemukan nilai esoteris yang mendasari kehidupan dalam kerangka transformasi sosial keagamaan. Menegaskan bahwa Islam tidak hanya membahas masalah klasik dan teologis Fiqh, tetapi juga mengilhami umat manusia untuk menghakimi dan memperlakukan sesama manusia sebagai makhluk Tuhan yang bermartabat dan bermartabat sehingga wajar untuk dihormati dan diperlakukan secara adil.

Kata Kunci: feminisme; fiqh woman critiq; studi islam kontemporer; keadilan gender

Permalink/DOI: https://doi.org/10.15408/harkat.v14i1.10403 


\section{Pendahuluan}

Modernitas di sepanjang sejarah perkembangannya secara kental diwarnai oleh teori dan gerakan feminisme dari Barat yang kemudian menjadi acuan melajukan perjuangan bagi wujudnya kesetaraan dan keadilan manusia dihampir seluruh penjuru dunia. Feminisme mula-mula menemukan adanya bentukbentuk ketimpangan social berbasis gender pada masyarakat yang bergayut pada pemahaman atas agama dan budaya. Feminisme sebagai sistem gagasan adalah kerangka kerja dan kajian dengan cakupanluas tentang kehidupan social dan pengalaman manusia yang berkembang dari persepektif yang berpusat pada perempuan. Sejarah panjangnya adalah cermin lika-liku bagaimana upaya-upaya mewujudkan keadilan bagi kemanusiaan.

Feminisme turut pula memantik kesadaran kaum muslim atas kenyataan adanya ketimpangan gender. Kesadaran tersebut mengantarkan pada pemahaman bahwa muara ketimpangan gender berawal dari disparitas atas pemaknaan nass/ teks keagamaan dengan realitas zaman (historisitas). Perkawinan antara teori feminis sebagai bagian dari teori modern menawarkan solusi masalah kemanusiaan melalui kajian tafsir kontemporer yang berimbang dalam menilai perempuan dan lakilaki. Menemukan nilai-nilai keislaman yang relevan dalam pengarusutamaan gender yang berdampak positif bagi keadilan sosial. Mengembangkan kajian Islam sebagai nilai esoteris yang mendasari kehidupan dalam kerangka transformasi sosial keagamaan. Menegaskan bahwa Islam tidak semata mengusung persoalan Fikih klasik dan teologis, namun juga menginspirasi manusia untuk menilai dan memperlakukan sesama manusia sebagai makhluk Allah yang memiliki harkat dan martabat sehingga adalah wajar untuk dihormati dan diperlakukan dengan adil. Pemikiran ini adalah wujud keterlibatan dunia akademis Islam terhadap upaya-upaya kongkret sebagai lembaga pendidikan tinggi dalam menyelesaikan masalah aktual di masyarakat dalam bidang sosial keagamaan.

Isu-isu tentang perempuan yang diusung oleh feminisme di dalam teori sosial sesungguhnya bukanlah gagasan baru, namun tidak bisa juga dikatakan sebagai ide yang telah ada sejak awal mula perkembangan teori sosial. Teori feminis bisa ditandai sebagai buah pemikiran yang lahir dari friksi sosial yang kemudian turut menyemarakkan modernitas dan menyeruak di dunia akademis Barat sejak tahun 60-an dalam nuansa borjuis liberal, di mana masyarakat mau tak mau harus mengubah pemahamannya tentang konsep gender dan "warga negara" dalam menjawab tuntutantuntutan kaum feminis. Bersamaan dengan berkembangnya kondisi social.

zamannya, feminisme kemudian merubah tuntutan-tuntutan berdasarkan arah kebutuhan dalam kehidupan kaum perempuan yang lebih berkeadilan.

Pada abad ke-empat belas sudah mulai ditemukan gagasan-gagasan dari para penulis perempuan yang berusaha mempertanyakan tempat (posisi) mereka di dunia sosial dan menentang ide-ide tentang feminitas yang dianggap wajar dan berlaku ketika itu. Kajian dan penulisan tentang persoalan sosial yang mengabaikan "kehadiran" perempuan tersebut tidak melulu dilakukan oleh perempuan sendiri seperti; Judith Butler, Wolstoncraft dan Simone de Beauvoir, namun juga oleh banyak feminis laki-laki sebagaimana John Stuart Mill, Karl Marx, Mao Se Tung, Michel Foucault dan Sigmund Freud. Perdebatan tentang bagaimana seharusnya perempuan diperlakukan dalam konstelasi politik dan sosial terus berlangsung selama berabad-abad dan menuju puncaknya pada paruh ke dua abad dua puluh di mana isu yang di kemukakan mengalami pergeseran dari ranah natur ke kultur, domestik ke publik, 
rumah tangga ke pabrik, menuntut hak perempuan dalam politik untuk menjadi peserta pemilu, mendapatkan perlindungan dalam undang-undang serta hak untuk sepenuhnya memiliki dan mengelola tubuhnya sendiri. apa saja tema-tema yang berkembang di feminisme terlebih dalam dua ratus terakhir dan bagaimanakah dampak serta relevansinya bagi kajian keislaman akan dibahas lebih jauh dalam pembahasan berikut.

\section{Metode}

Dengan menggunakan penelitian deskriptif bertujuan agar dapat menggambarkan berbagai fenomena realitas sebenarnya yang menjadi obyek penelitian agar lebih mendalam dan memperoleh data yang diinginkan dengan melihat dan mempelajari teori feminism dari kajian Islam kontemporer.

\section{Hasil dan Pembahasan}

Di dalam Kamus Besar Bahasa Indonesia (1997:3324) feminisme diartikan sebagai gerakan wanita yang menuntut persamaan hak sepenuhnya antara kaum wanita dan pria yang merupakan penggabungan dari pelbagai doktrin atas hak kesetaraan. Feminisme muncul dilatari oleh ketimpangan relasi antara laki-aki dan perempuan dalam tatanan masyarakat sehingga pada akhirnya timbul kesadaran dan upaya untuk menghilangkan ketidakberimbangan relasi tersebut. Pada praktek keseharian istilah feminisme sering disalahpahami hanya melulu sebagai tuntutan emansipasi kaum perempuan, padahal yang dimaksud dengan istilah tersebut mengacu pada gerakan sosial (social movement) yang dilakukan baik oleh kaum perempuan maupun laki-laki untuk meningkatkan kedudukan dan peran kaum perempuan serta memperjuangkan hak-hak yang dimiliki oleh keduanya secara adil.
Berkaitan dengan itu, muncullah istilah equal right's movement atau gerakan persamaan hak, suatu upaya untuk membebaskan perempuan dari ikatan lingkungan domestik atau lingkungan keluarga dan rumah tangga. Cara ini sering dinamakan women's liberation movement yang disingkat women's lib atau women's emancipation movement, yaitu gerakan pembebasan wanita. Pada dasarnya feminisme merupakan implementasi dari kesadaran untuk menciptakan keadilan gender dalam kerangka demokratisasi dan HAM (Hak Asasi Manusia). Gerakan tersebut diperkirakan muncul seiring dengan ideologi aufklarung (enlightment) yang muncul di Eropa antara akhir abad ke- 14 sampai abad ke- 18. Gagasan yang dominan pada waktu itu adalah paham rasionalisme yang ditandai dengan pemujaan akal, pikiran dan rasio. Ide rasionalisme mempengaruhi lahirnya revolusi Perancis (1789-1793) yang menggunakan slogan kebebasan dari penindasan (liberte), pengakuan terhadap persamaan hak (egalite) dan semangat persaudaraan (fraternite) sebagai semboyan untuk meruntuhkan rezim kerajaan yang otoriter yang digantikan dengan kekuasaan republik yang menggunakan sistem demokrasi. Pada masa ini kasus Marie Antoinette menjadi bidak yang melesakkan isuisu perempuan ke muka dunia.

Gerakan panjang akan kesetaraan hak tidak serta merta bisa membuat perempuan menikmati hasil dari perjuangan tersebut. Karena setelah revolusi Perancis, peraturan-peraturan yang merugikan perempuan tetap berlaku dan disahkan kembali. Dari sejarah gerakan perempuan di Perancis tersebut menunjukkan bahwa perempuan tidak serta merta mendapatkan hak yang sama dengan laki-laki meskipun telah muncul gagasan liberte, egalite dan fraternite sebagai nilai-nilai universal kemanusiaan. Hegemoni patriarki dan kuatnya sistem sosial budaya yang mengakar menghambat geliat perempuan dalam menuntut keadilan. 
Mary Wollstonecraft (Turner, 2012:337) perintis gerakan feminisme Inggris dalam karyanya $A$ Vindication of the Rights of Woman (Perlindungan Hak-hak Kaum Wanita) yang ditulis di akhir abad ke-19 mengemukakan bahwa kaum wanita, khususnya dari kalangan menengah merupakan kelas tertindas yang harus bangkit dari belenggu rumah tangga. Dalam masyarakat patriarkal, perempuan dimasukkan ke dalam kubu rumah yang terbatas pada lingkungan serta kehidupan di rumah, sedangkan laki-laki menguasai kubu umum, yaitu lingkungan dan kehidupan di luar rumah. Perempuan seringkali berada dalam situasi keterikatan. Ketidakmerdekaan perempuan sebagai manusia dalam menentukan hak, kewajiban, dan tanggung jawabnya sendiri. Situasi ketidakadilan tersebut muncul karena struktur budaya yang dibuat oleh manusia, dan bukan sesuatu yang alamiah sebagaimana yang sebelumnya diyakini oleh banyak budaya di belahan dunia (Foucault, 2017:237-249).

Wollstonecraft _ senada dengan Marx_ meyakini bahwa dalam konteks abad keduapuluh satu derajat emansipasi perempuan akan berhubungan dengan kemajuan umum dan menjadi pencerahan bagi masyarakat secara keseluruhan. Posisi perempuan dalam masyarakat haruslah dinilai dalam pengertian masyarakat sebagai satu keseluruhan yang utuh. Dalam hal ini J.S Mill (2005:143-182) memiliki pandangan bahwa perbaikan dari satu bagian kecil dari dunia sosial bukanlah soal mengubah satu konteks saja, melainkan mengubah seluruh pertimbangan dan penataan ulang berbagai bagian dari dunia sosial. Selama dua ratus kemudian perdebatan feminisme paska gaya Wollstonecraft masih terus memperjuangkan perlakuan yang setara antara laki-laki dan perempuan baik di ranah sosial maupun domestik. Gerakan tersebut masih terus mengalami perlawanan dari kaum konservatif yang meyakini bahwa secara "alamiah" antara laki-laki dan perempuan memiliki perbedaan yang tidak mungkin diubah.

Jika dicermati, sepanjang abad 19 sampai dengan 20, ada dua corak tradisi dalam diskusi "keperempuanan". Kelompok pertama adalah para pemikir yang mengembangkan wacananya di Inggris dan Amerika; seperti J.S. Mill, Brontes, George Eliot dan Elizabeth Gaskell. Isu yang diusung adalah pentingnya pendidikan tinggi dan profesionalitas bagi kaum perempuan disamping terus memperjuangkan hak pilih perempuan dalam pemilu sebagai gerakan perubahan posisi perempuan dalam keseluruhan sistem sosial. Kelompok kedua adalah yang dipelopori oleh Marx dan Engels (1984:388), keduanya menyepakati akan pentingnya hubungan antar struktur masyarakat dan membagi peran kerja bedasarkan jenis kelamin. Dalam sistem masyarakat sosialis emansipasi perempuan patut dipertimbangkan mengingat kebutuhan akan peran mereka pada ranah kerja publik di sektor industri. Meskipun tampak berbeda namun pada dasarnya corak feminisme abad 19 memiliki kemiripan titik pijak penilaian bahwa antara laki-laki dan perempuan yang dalam term mereka adalah male dan female, maskulin dan feminin sebagai hal yang melekat pada jenis kelamin memiliki perbedaan mutlak yang dianggap alamiah dan akan terus dipertahankan dalam tata masyarakatnya, tidak akan bisa berubah walau apapun yang akan terjadi dalam penataan sosial model lainnya.

Masih pada abad 19, Sigmund Freud memunculkan pergeseran sudut pandang yang signifikan terhadap diskursus keaslian sifat lakilaki dan perempuan yang tidak bisa dirubah yang selama berabad-abad yang seakan membatu. Menurutnya yang terpenting adalah memberikan satu bagian penting (krusial) bagi kaum perempuan di dalam hubungan-hubungan sosialnya, baik secara material maupun simbolik yang dengan bagian itu didapatkan identitas seksual. Mendapatkan "maleness" maupun 
"femaleness" dalam kehidupan seseorang bukanlah tanpa suatu masalah. Tugas menjadi pejantan, menjadi betina sebagai suatu penugasan sosial sebagai penjaga makna bisa jadi mengalami perubahan serta perbedaanperbedaan.

Paska Freud muncul Simone De Beauvoir yaang dianggap sebagai ikon ke dua feminisme abad ke duapuluh dengan The Second Sex-nya yang terbit pada 1949. Beauvoir mengiyakan Freud akan pemahamannya tentang laki-laki dan perempuan, jantan dan betina yang diorganisir di seputar divisi biner yang rigid. Namun lebih jauh Simone de Beauvoir mengangkat alokasi perempuan pada wilayah domestik dan kepasifan. Ia memberontak atas penyingkiran terhadap perempuan dari agensi sosial dan emosional. Simone de Beauvoir mendesak kaum perempuan untuk melangkah keluar dari batasan-batasan yang didefinisikan secara sosial dan menjadikannya sebagai "sang liyan" (the other). Pada kurun ini menurut Simone de Beauvoir, perempuan hidup dalam kedunguan dan hanya menjadi pengikut yang selamanya bersenang hati menjalankan perintah serta menerima begitu saja definisi-definisi kaum lelaki tentang realitas. Para perempuan sibuk bersaing untuk mengakses para pria yang disebutnya dengan "pejantan-pejantan alpha”.

Simone de Beauvoir dalam perjuangannya menyebarkan gagasan di Eropa sangat menarik, penting baginya untuk mewujudkan otonomi kaum perempuan terhadap kontrol atas teknologi dan reproduksi. Bahasa dan kecerdasan menurutnya adalah hal yang netral gender, tidak ada bahasa perempuan sama halnya degan tidak adanya bahasa laki-laki, melalui bahasa yang sama maka cara berfikir keduanya pun sama. Lebih jauh dinyatakannya bahwa "perempuan" sebagai sifat gender dibuat oleh struktur masyarakat dengan watak kelabilannya, yang ditetapkan maknanya pada konteks sosial yang berubah-ubah. Menurutnya, sesungguhnya "perempuan diciptakan bukan dilahirkan" (women are made and not born).

Ada gambaran bahwa isu yang diangkat oleh feminisme awal sampai dengan Simone de Beauvoir adalah model eksistensi manusia yang emansipatoris sebagai usaha perbaikan dunia sosial. Membidik isu ke-ibu-an yang dianggap sebagai penghambat emansipasi publik bagi kaum perempuan. Mereka berjuang untuk mendapatkan hak atas pengendalian tubuh dan mendapatkan pengakuan sosial sebagai agenagen seksual yang otonom. Perjuangan panjang selama dua ratus tahun tersebut rupanya terakselerasikan oleh perang dunia I dan II dan berlanjut dengan revolusi konsumen pada tahun 1950-an yang menyedot sekian banyak tenaga kerja perempuan. Perang dengan demikian menjadi faktor yang sangat mempengaruhi perubahan sosial. Perempuan yang awalnya "bermain" di rumah pada 1940 dan 1945 menyerbu sektor produksi, apalagi mereka yang lajang. Feminisme gelombang pertama ini ditandai akhirnya dengan munculnya istilah invented sex, jenis kelamin buatan yang kemudian mengantarkan perempuan pada dunia yang dipenuhi nuansa "women's liberation", pembebasan perempuan yang demikian populer.

Pada tahun 1960-an dan 1970-an feminisme tidak memiliki massa yang signifikan secara kuantitas, namun demikian jumlah yang sedikit tak membuat suara mereka melirih, sebaliknya semakin kencang dan menarik perhatian. Pada saat itu perempuan tidak dalam kondisi miskin secara material karena Eropa telah makmur. Namun demikian perempuan berada dalam posisi Thralldom (keadaan di bawah kekuasaan orang lain, terikat seperti budak). The Feminin Mistique, menggambarkan bagaimana di daerahdaerah sub urban yang makmur, perempuanperempuan berpendidikan mengalami ketertekanan karena terkurung di dalam rumah dan terjebak pada lingkaran domestik. Mengelola keuangan namun tidak berhak untuk 
berkreasi atasnya. Friedan kemudian menjadi semacam kerikil yang melemparkan kesadaran kepada banyak pemerhati perempuan bahwa harus ada revolusi untuk mengubah sikap masyarakat tentang gender.

Banyak nama yang bisa disebut pada periode ini; Germaine Greer, Kate Millet, Sheila Rowbotham, Eva Figes dan Shulamith Firestone. Mereka tidak lagi membahas bagaimana bentuk ideal lembaga pengasuhan anak sebagai dampak perubahan-perubahan tertentu dalam tatanan sosial, namun mengarah pada dua terma; pertama tentang misogini sebagai suatu sikap budaya membenci perempuan yang telah tertanam begitu dalam di bawah kesadaran masyarakat, sehingga menjadi begitu lazim dalam praktik-praktik sosial. Kedua, tentang pembagian kerja yang didasarkan pada jenis kelamin. Pemahaman ini adalah anak yang lahir dari rahim konstruksi kapitalisme neo-liberal (Turner, 2012:401). Meski demikian yang lebih banyak ditulis oleh kaum feminis bukan tentang kondisi-kondisi kerja dan para pekerjanya, namun tentang kondisi-kondisi seksualitas. Mereka menyuarakan akses terhadap kontrasepsi dan aborsi bagi perempuan. Fasilitas pengasuhan anak ke seluruh bagian negara, upah yang adil dan perlakuan yang sama di hadapan hukum.

Kaum feminis mencapai prestasinya di Inggris pada tahun 1967 dengan disahkannya sejumlah undang-undang yang menata ulang seksualitas dan perkawinan. Perubahan di Inggris tersebut mengilhami negara-negara lain dan menjadi semacam gerakan perubahan pada tahun 1970, sehingga apa yang selama 20 tahun sebelumnya dianggap sebagai sesuatu yang mustahil telah diintrodusir oleh mayoritas masyarakat Barat pada tahun 1980an. Perubahan tatanan sosial yang demikian cepat sering digambarkan sebagai revolusi seksual yang dengan demikian kebebasan personal bagi warga negara secara individual terbuka lebar. Pada akhir abad ke dua puluh terjadi perkembangan intelektual feminis yang luar biasa sebagai dampak terbukanya akses pendidikan tinggi bagi mereka. Perempuan menjadi biasa ditemukan di perguruan-perguruan tinggi ternama dan mengambil pengaruh penting, yang tentu saja tidak tanpa tantangan atau nir perjuangan.

Isu kekinian yang diangkat oleh kaum feminis adalah; pertama, mendefinisikan kembali istilah-istilah "alam/ sifat" "gender" dan "hakhak" yang telah lama terabaikan dari perdebatan akademis. Kedua adalah tantangan terhadap asumsi-asumsi gender dalam berbagai tradisi disipliner "klasik". Harus diakui bahwa di Barat isu-isu feminis tidak lagi sepesat dan sedinamis periode sebelumnya. Bisa jadi hal ini diakibatkan oleh telah terbukanya kebebasan individu sebagai warga negara untuk menegaskan identitasnya sebagai bentuk pengakuan_untuk tidak mengatakan pemujaan_atas pluralirisme liberal. Hari-hari ini ada semacam selebrasi dan euforia di Barat akan keragaman yang tidak hanya di dasarkan pada ras, etnis dan agama saja, namun juga pilihan jenis kelamin, gender dan orientasi seksual yang semakin bersaling lintas.

Pertanyaan yang masih tersisa adalah adakah perbedaan yang khas dan tak mungkin diubah antara laki-laki dan perempuan yamg mewujud dalam cara memahami dan bertindak di dalam dan terhadap dunia. Perbedaan yang dianggap essensial tersebutlah yang kemudian menjadi corak feminisme essensialis kontemporer di Barat, padahal sebelumnya isu-isu tersebut adalah hal yang tidak bisa diterima (akhir 1980an). Kekuatan retoris dan manfaat konsep perbedaan "esensial" antara laki-laki dan perempuan yang paling kuat diekspresikan pada tahun 70an adalah bahwa "semua laki-laki adalah pemerkosa” yang sekarang ditolak, sama rumitnya dengan integritas kata "woman" yang secara politis bermakna penting namun dalam konteks sejumlah besar tradisi pemahaman konstruksi sosial atas self juga menjadi problematik. 
Gender Trouble yang terbit pada 1990 mendobrak kelambanan esensialisme dengan mengajukan gugatan bahwa gender menempati posisi sentral, bukan lagi jenis kelamin. Tanpa gender dan diferensiasinya, komponen masyarakat tidak bisa berfungsi. Butler menawarkan suatu cara untuk memisahkan berbagai ideologi tentang maskulinitas dan feminitas bukan hanya dari orang-orang yang secara biologis laki-laki atau perempuan tetapi juga dari serangkaian ide apapun yang berasumsikan tatanan gender "yang alamiah". Dinyatakannya bahwa gender adalah konstruksi sosial dan pilihan individual, bukan alamiah. Dalam perspektif Butler, gender secara mudah bisa dipahami sebagai suatu konsep yang digunakan untuk mengidentifikasi perbedaan peran laki-laki dan perempuan dilihat dari segi sosial budaya yang bertumpu pada harapanharapan, bukan dari ciri fisik jenis kelamin yang permanen.

Perempuan sebagai bagian dari masyarakat dunia, adalah juga manusia yang harus diakui harkat dan martabatnya. Dalam narasi teologis diajarkan bahwa Allah memerintahkan kepada manusia untuk menjunjung dan menegakkan nilai ideal Islam agar senantiasa bersikap adil dan berbuat baik dengan menggunakan istilah al-adl dan ihsan (2000). Kajian Islam Kontemporer dengan demikian harus menyentufh dan menjadikan persoalan perempuan dalam konteks keislaman dari perspektif sosiologis sebagai kajian yang penting. Fikih perempuan kontemporer (Fiqh al-nisa' al-mu'asirah) dengan kompleksitas persoalan kekiniannya masuk sebagai kajian yang dianalisa dengan menggunakan metodologi ilmu sosial baru sebagaimana yang ditawarkan oleh feminisme.

Kajian multidisipliner terkait persoalan keperempuanan dalam ranah agama dan sosial, saat ini mendesak untuk dilakukan mengingat bahwa Fikih perempuan klasik umumnya lebih melihat wanita atau perempuan dari perspektif biologis saja, sehingga dalam teks tradisional (kitab kuning) yang menjadi persoalan hanya tentang haid atau menstruasi, jenis najis dari air seni, mughaladhah atau mukhaffafah, masa tenggang iddah, suara wanita termasuk aurat / bagian tubuh yang harus ditutupi dalam hubungannya dengan peribadatan atau ritual. Agar lebih komprehensif Kajian Islam Kontemporer (2000) hendaknya lebih diarahkan dari perspektif sosiologis, yakni peran sosial perempuan dalam kehidupan yang luas di tengah masyarakat dunia. Kebutuhan analisis atas persoalan keagamaan terkait perempuan sesungguhnya tidak hanya perspektif sosiologis, tetapi juga antropologis, psikologis, politik, hukum, budaya, seni dan lainnya. Dari sini dalam kajian sosiologi agama lalu muncul analisis tentang wanita yang dibedakan dalam dua perspektif; sex (biologis) dan sosiologis (gender).

Dalam konteks perkembangan budaya masyarakat muslim dunia, keberhasilan pendidikan (the rise of education), khususnya untuk wanita, telah menghadirkan cara dan kesadaran baru dalam melihat peran sosial perempuan dalam masyarakat. Jika pada era pramodern, bahkan era pra-scientific, kehidupan publik seolah-olah hanya milik pria, sekarang harus juga melibatkan kaum perempuan atau lebih bagus lagi jika kaum perempuan sendiri yang memiliki kesadaran atas kemampuan pribadi dan kemudian melibatkan diri. Sebab tak lagi layak mengkategorikan perempuan yang dalam terminologi Jawa disebut sebagai "konco wingking" (dianggap kehadirannya hanya pada ranah domestik belaka). Para perempuan telah memiliki konsep bagaimana mengelola ruang dan kehidupan publik bersama-sama pria. Bahkan dalam konteks bernegara saat ini siapapun harus sadar bahwa hak-hak perempuan dalam kehidupan publik (public area) harus juga dipenuhi sebagai warga negara yang setara dengan para pria. Kepemimpinan sosial-politik 
dan profesi apapun harus share antara pria dan wanita.

Tugas perempuan untuk melahirkan anak yang semula dianggap sebagai tugas alamiah, sekarang dalam perspektif sosiologi agama diangkat ke atas, ke tingkat yang lebih tinggi, yaitu apa yang disebut dengan hak-hak reproduksi. Jika dahulu tugas tersebut hanya dilihat secara alamiah (nature), sekarang tidak begitu lagi. Pemenuhan hak-hak reproduksi adalah mandat kemanusiaan dan tugas pemerintah serta masyarakat luas untuk memenuhinya. Namun demikian di lapangan tidak mudah mewujudkan kesetaraan dan keadilan gender bagi kaum perempuan, karena pemahaman atas kesetaraan gender sangat terkait dengan banyak hal, utamanya dengan budaya (nurture) dimana peran atas pemahaman dan penafsiran agama sangat luar biasa besar pengaruh dan hegemoninya (246-249).

Beberapa tantangan feminis Kontemporer adalah hak-hak reproduksi; tentang usia perkawinan yang ideal, masih tingginya angka kematian ibu, keluarga berencana, pendidikan kesehatan reproduksi. Di luar itu muncul juga persoalan tentang gender-based budget, politik anggaran pemerintah pusat dan daerah untuk memberdayakan perempuan. Dengan demikian fenomena marginalisasi dan sub-ordinasi perempuan terjadi diakui atau tidak memang terjadi di seluruh lini kehidupan; sosial, politik (kepemimpinan politik), ketenagakerjaan (upah pekerja wanita, cuti hamil, menyusui anak), adanya beban ganda (double burden) yang dialami para wanita pekerja, kerja di dalam rumah dan di luar rumah.

\section{Simpulan}

Problem yang tak kalah urgennya adalah tuntutan atas perubahan arah dalam kajian hukum keluarga / Ahwal as-syakhsiyah terkait dengan nikah siri, poligami, perwalian, pengasuhan anak dan hak waris. Hakim wanita, saksi perempuan dalam peradilan, hijab (masih banyak yang belum tersebut) adalah problem sosiologis yang lahir sebagai akibat hegemoni budaya patriarki yang sesungguhnya berkelindanan dengan konteks pemahaman masyarakat pada masanya. Persoalan-persoalan tersebut hari ini diungkap ke permukaan tidak hanya sebatas wacana tetapi sebagai gerakan. Tak terhitung lembaga swadaya masyarakat di tanah air yang membidangi penguatan hak-hak perempuan (2013). Bahkan pemerintah pun juga mempunyai kementrian khusus yang membidangi pemberdayaan perempuan dan perlindungan anak. Melalui pergulatan hebat perjuangan tersebut pada akhirnya sampai pada suatu kesimpulan bahwa muara atas ketimpangan-ketimpangan tersebut banyak disumbang oleh world view atau tafsir religiososiologis lama yang dikonstruk oleh para penafsir/mufassir atas nass-nass al-Qur'an dan alHadits (al-Ghazali, 1989:36-61). Dalam analisis gender, muncul pengkategorian baru atas hadis yang belum ditemukan dalam kitab hadis sebelumnya, yaitu apa disebut dengan hadishadis misoginik, hadis-hadis sosial yang kurang menghargai perempuan sebagai manusia otonom dengan harkat dan martabat kemanusiaan sebagaimana laki-laki.

Dengan demikian pemahaman dan penafsiran atau singkatnya "tafsir baru" atas teks keagamaan yang terkait dengan permasalahan perempuan di tengah masyarakat di seluruh dunia menjadi niscaya. Penjabaran di atas menghadirkan kegelisahan akademis yang menjadi pekerjaan rumah bagi keilmuan Islam saat ini. Islam sebagai agama pembebas menyadarkan dan mendorong ilmuwan muslim progresif untuk melakukan penelitian dan kajian ulang terhadap kitab-kitab tafsir klasik terkait.

Dengan penafsiran dan pemahaman para mufasirnya tentang perempuan yang pasti berdasar pada realitas perempuan pada zamannya 
dan kemudian di perbandingkan dengan kebutuhan tafsir baru yang lebih sesuai dengan perubahan sosial dan tuntutan zaman saat ini.

Teori Feminis sebagai teori kritis turut mewarnai perdebatan dalam kajian keislaman. Memunculkan riak-riak dinamis dalam berbagi diskursus; Tafsir, Hadis, Syari'ah, Jinayah, Siyasah, Adab dan Filsafat. menarik untuk digunakan sebabai perspektif dalam Kajian Islam Kontemporer terkait dengan Fikih Perempuan karena berbeda dengan kebanyakan teori sosial yang lain. Feminisme adalah kerja interdisipliner, multikultural dan komunitas, sehingga sangat terbuka bagi persoalan-persoalan perempuan dalam konteks geografis dan budaya dimanapun dan kapanpun. Feminisme juga memiliki agenda ganda; memperluas dan memperdalam sosiologi dengan mengulang pekerjaan pengetahuan dalam suatu disiplin ilmu untuk membicarakan temuan-temuan yang dilakukan oleh para intelektual feminis dan mengembangkan pemahaman kritis atas masyarakat dalam rangka mengubah dunia ke arah yang diyakini lebih adil dan lebih manusiawi. Mengingat bahwa kesetaraan dan keadilan gender dalam Islam sesungguhnya sama tuanya dengan ajaran tentang sholat dan zakat. Pada zaman Rosulullah dari tidak pernah disebut perempuan tiba-tiba dimunculkan. Mereka diperhitungkan dalam penetapan hukum; waris, nikah, jihad dan diposisikan secara terhormat dalam tatanan sosial.

Pada perjalanan waktu, kentalnya nuansa politik melibas hampir seluruh nama dan peran perempuan dalam kesejarahan dan peradaban Islam. Hal ini menjadi suatu tantangan bagi para sarjana muslim untuk menguak lebih jauh apa yang sesungguhnya terjadi. Karena dampak dari mengakarnya tafsir dan penerapan hadits misoginis telah berabad-abad mengungkung kehormatan perempuan, yang sebelumnya telah dengan tegas di angkat oleh Rosulullah dan bahkan diwasiatkan penjagaannya saat haji
Wadak. Di Indonesia sendiri pascka reformasi, terbentuknya otonomi daerah menggiring munculnya perda-perda misoginis yang seringkali mengobyektifikasi perempuan dan selalu disandarkan pada teks kitab suci.

\section{Daftar Pustaka}

Bryan. S. Turner, ed., 2012, Teori Sosial : dari Klasik Sampai Post Modern, Yogyakarta: Pustaka Pelajar.

John Stuart Mill, 2005, On Liberty, Terj. Alex Lanur, Jakarta: Yayasan Obor Indonesia.

Marx dan Engels, 1984, The Origins of the family, private Property and the state, London: Penguin

Michel Foucault, 2014, Power Knowledge, Wacana Kuasa Pengetahuan, Terj. Yudi Santosa, Yogyakarta: Narasi dan Pustaka Promothea

Muhammad al-Ghazali, 1989, al-Sunnah alNabawiyyah baina ahl al-fiqh wa ahl alhadits, Beirut: Dar al-syuruq.

Nasr Hamid Abu Zaid, 2000, Dawair al-Khauf: Qira'ah fi Khitab al-mar'ah, Bairut: alHamra'.

Simone de Beauvoir, 1989, The Second Sex Kehidupan Perempuan, New York: Vintage, Terj. Toni B Febriantono dkk, 2014, Yogyakarta: Narasi dan Pustaka Promothea

George Ritzer \& Douglas J Goodman, 2004, Teori Sosiologi Klasik Sampai Perkembangan Mutakhir Post Modern, Terj. Nurhadi, Yogyakarta: Kreasi Wacana

Tim Bahasa, Kamus Besar Bahasa Indonesia, 1997 Jakarta: PT. Gramedia Pustaka Utama.. 